\title{
Linnés latin
}

\section{Av Erik Wiberg}

\section{Linnés språkliga värld}

Jag kommer i denna artikel att behandla Carl von Linnés språkliga värld och hans bruk av det kulturella massmedium som latinet var på hans tid.

Först kan vi se att vår huvudperson hade en gynnsam miljö för språkets odling. Att finnas i en prästgård på landet gav i sig förutsättningar för att man aldrig skulle behöva vara utan stimulans bokligt och socialt. Prästgården var ju på den tiden ett socialt och intellektuellt nav i hela socknens liv, dit många hade anledning att vända sig, resande kom och gick och nyheter utifrån världen letade sig dit. Prästbarnen levde i den unika och fruktbärande myllan mellan det vardagligt slitsamma och praktiska liv som hörde samman med naturen, de lokala människorna men också tillgången till en annan värld av boklig bildning, intellektuell kunskap och andlig odling. Linnés far, Nils Linnaeus, var en försynt och stillsam man som hade ett stort intresse vid sidan av sitt yrke. Han älskade blommor och odlade dem i sin trädgård i Stenbrohult, en sevärdhet genom sin artrikedom. Till sonen förmedlade han en närhet och förtrogenhet med denna värld, som slog rot och skulle visa sig bära livsvarig frukt. I hans fars bibliotek fanns också böcker på latin. Förutom dogmatik, urkunder och uppbyggliga verk fanns, t.ex. Aristoteles' Zoologi i översättning till latin. Jag vill gärna tro att denna ordnade, tabellariska värld av mystik underblåste hans kärlek till blommornas värld.

Vi skall återkomma till hans latinska skolning; men redan nu kan vi konstatera att det sätt på vilket ämnet överfördes under hans tidiga år, genom informatorn Johan Thelander och vidare i trivialskolan och gymnasiet i Växjö inte hade gynnsam effekt.

Låt mig först beröra det bildningssystem som Linné kom att vistas i. Det hade sin rot $\mathrm{i}$ begreppet enkyklios paideia, en krets av vetande som cirklade kring de huvudmaterier man i västerlandet ansett att en bildad människa borde bli insatt i. Detta ideal kom att realiseras i septem liberales artes de sju fria konsterna, indelade i trivium: grammatik, retorik och dialektik och quadrivium: musik, aritmetik, geometri och astronomi. I klartext betydde dessa grundläggande kunskaper i läsning, skrivning och räkning, ett närstudium av den klassiska litteraturen och dess språk, litteratur och muntliga behandling.

På skolans tablå, dvs. kursplan, fördelades dessa ämnen i elementarskola 7-9 år, trivialskola omfattande de fyra följande åren och sedan gymnasiet, omfattande åldrarna 14-17. I den av Rudbeckius formerade och av drottning Kristina undertecknade skolordningen av år 1649 blev detta skolsystem i detalj reglerat med tyngdpunkten på ett teologiskt förankrat och fast organiserat latinläroverk, som skulle bestå i två århundraden.

Latinet var vetenskapens och bildningens språk i hela Europa, och alla som genomgått gymnasiet förväntades behärska det. För att lära sig latin krävdes flitigt övande och varje svensk gymnasist på 1600-talet hade ca 20 veckotimmar i latin på schemat. 
Hur såg då de lärdes språkvärld - res publica literaria - ut på Linnés tid? Om själva koden var latinet, så var de olika sociolekterna åtskilliga. Språkhistoriskt sett befinner vi oss på nylatinets område (ca 1500-1800.) Språket är sedan länge ett artificiellt och specialiserat kommunikationsmedel inom främst vetenskap, lärdom och skolor, men också en självklarhet för bildade som önskade ha tillgång till sin historia och det samtida vetandet. Det var den kulturella och vetenskapliga världens lingua franca, väl att jämföra med motsvarande betydelse hos dagens engelska. Det bör ändå nämnas att språket inte stod ohotat vid denna tid. Inom diplomatin dominerade franskan. De nationella munarterna var på frammarsch, inte minst i de näringar och på de områden där man ville markera det speciella för ett enskilt land eller kulturområde.

Den normerande källan och användningen var det klassiska latinet, i synnerhet Cicero, vars breda spektrum av ord och stilarter, konstfärdiga syntax förblev humanistens och vältalarens ideal. Men nylatinet rymde också andra stilsorter. En sådan var det taciteiskt-senecanska stilidealet. Det präglades av korthet och kompression. Till dess anhängare kunde räknas naturvetare, jurister, stats- och hushållningsvetare. Deras behov var ett ändamålsenligt, deskriptivt språk utan utsmyckningar och med fast och definierad begreppsapparat. Det säger sig självt att det kom att röra sig om att anpassa gängse ord och nybildningar på äldre rötter, eftersom det gällde att skildra också nya företeelser.

Vetenskapshistoriskt befinner vi oss också i en tid när olika traditioner möts och prövas. Den aristoteliska traditionen av empiri och logik grundad en verklighetsförståelse som betonade den transformerade och transformerande kraften och ändamålsenligheten i all materia (hylozoismen) mötte nya tankeriktningar, som cartesianismen efter René Descartes (15961650), som med sin kunskapsradikalism gjorde kunskapsteorin till filosofins grundläggande disciplin och ansåg att den materiella verkligheten - res extensa - endast kunde göras till föremål för säker kunskap, medan medvetandet - res cogitans - tillhörde en annan och högst problematisk kategori. John Locke, den engelske empirikern (1632-1704), förespråkade, som den för tiden och framtiden tongivande filosofen, följande i An Essay concerning $\mathrm{Hu}$ man Understanding, 1690, s. 325:

The ends of language in our discourse with others being chiefly these three: First, to make known one man's thoughts or ideas to another. Secondly, to do it with as much ease and quickness as is possible; and, thirdly, thereby to convey the knowledge of things. Language is either abused or deficient when it fails any of these.

Begreppskorthet och begreppsklarhet var tidens lösen. Linné läste och införlivade de här antydda traditionerna och förhållningssätten, tillsammans med fysikoteologin, en vid den tiden fullt accepterad hållning som antog att det var människans uppgift som förvaltare av skapelsen att avlocka den dess hemligheter - däribland att tyda och koda Guds verk - för att därmed ära honom.

\section{Linnés tidiga latinreception}

I fallet Linné kan det både vara givande och intressant att se på hur hans förtrogenhet med språket latin formades och formerades. Inte minst mot bakgrund av de påståenden som gjorts 
om hans förmåga att ta till sig språket, särskilt under skolåren, men också att senare bruka det med framgång.

Carl von Linnés tidiga umgänge med språket blev litet kluvet. Han fick influenser från sin far, människor som besökte prästhemmet och från de böcker i botanik som han läste. Troligen fick den unge Carl tidigt upp ögonen för ord som förmedlade en kunskap om de ting som var honom kära.

Men han fick också en ganska råbarkad informator, vilket kan vara orsaken till hans relativa misslyckande i skolan. Carl tvingades lära sig utantill, något som passade just honom särskilt illa, som ville se samband och få allt förklarat. Trivialskolan och stora delar av gymnasiet enbart förstärkte hans olust för att lära på det sättet.

Vi skall dock inte tro att allt var mörkt under denna gropiga resa. Linné hade turen och förmågan att i trängda lägen finna eller vinna människor för sin sak. Daniel Lannerus, rektor på trivialskolan, var hans lärare under sista året, och var något av en botanist, och kände också Carls far. Med honom verkar Carl ha kommit väl överens. Under senare delen av gymnasiet fann han äntligen någon som förstod sig på hans egenheter. Det var provinsialläkaren i Växjö, tillika physices lektor Johan Rothman. Av honom fick han undervisning i naturvetenskaper i slutet av sin skoltid, och särskild undervisning i medicin och botanik, inklusive insikt i den nya systematiken. Det var vid denna tidpunkt som han antog kallelsen att bli en Floras präst och inte bifalla sina föräldrars, i synnerhet moderns, önskan om att gå teologins väg.

Sammanfattningsvis kan sägas att den färdighet han enligt Växjölektorernas mening uppnådde i ämnet var skral. Det vill säga han behärskade inte grammatik, syntax och översättning på det sätt som förväntades av en kyrkans tjänare in spe. Sin förmåga att ta till sig moderna språk, har han själv kommenterat på följande vis: Han var i hela sin tid främmande för att lätt lära in alla språk och påpekade frankt: "Linguas addiscendas minime aptus" ('Han var alls inte lämpad för att lära sig språk') (Malmeström, 1957, s. 179). Linné ansåg att det endast berodde på brist på tid och tålamod. Vidare har han yttrat sig om sitt bruk av latinet, något som var sällsynt: "Han sade sig häldre willia få af Prisciano tre slag än af naturen ett"1

Ett slags komplex för bristande precision och perfektion borde ha blivit följden av detta.

Det är inget vi kan spåra i hans levnadsbeskrivningar. Tvärtom kan vi anta att han fått med sig ett försvarligt bagage av både formell och kulturell kunskap om antiken och dess språk.

Det framgår med all önskvärd tydlighet av både hans vetenskapliga och hans övriga produktion.

Men när Linné kom till Lund och sedan till Uppsala fick latinet i olika former en större plats i hans liv. Han läste ansenliga mängder botanik, nomenklatur och systematik på detta språk. När han av Rudbeck anställdes som demonstratör 1730, hade han redan, som 23åring, det mesta av sin systematik uttänkt. Och grunderna för bruket av latin för hans egen del hade klarnat.

Det är på sin plats att något kommentera den lilla skara röster som under tiderna kritiserat Linnés latinbruk.

1 Priscianus (ca 500 e.Kr.) och Donatus (300-talet e.Kr.) var tongivande grammatiker under hela medeltiden och ett gott stycke framåt. 
Man måste göra klart för sig vad det är som kritiseras och ur vilken synpunkt. Den vanliga kritiken hör ofta ihop med bristande elegans och noggrannhet. Dessa omdömen förhåller sig till ett stilideal, som normativa stilister menar vara giltigt för var man och för alla ämnen och genrer. Och den latinska prosans ideal var Cicero. Den mest färgstarka nedsvärtningen av Linnés latin har Linnés porträttör Arvid Uggla gjort genom att beteckna det som Svartbäckslatin. ${ }^{2}$ Ugglas beteckning är grundlös och skjuter över målet. Frågan är om inte de kritiska rösterna i allmänhet gör det. De baserar sin kritik på för liten kunskap och för snäv vinkel. De ser inte den allt tydligare genredelningen, den mer varierade nylatinska normbilden och de ser inte till effektiviteten hos språket.

En viktig synpunkt har Ann-Mari Jönsson förmedlat: Det finns belägg för att originalkällorna under nylatinets tid (1500-1800), och i synnerhet under dess senare sekel egentligen inte så ofta konsulterades, utan hellre kompilationer och citatböcker. Jönsson anser också att det i Sverige före år 1850 saknades kunskap om mycket av vad vi idag vet om det klassiska latinet. Läro- och handböcker hade en sämre kvalitet, liksom lexikon. Man förlitade sig mycket på mnemotekniska regler och kokboksrecept (Jönsson 2000, s. 51).

Sedan är det ett faktum att Linnés penna slinter och att formsäkerheten inte är 100-procentig. Trots detta var han en effektiv kommunikatör; det visar hans stora produktion av vetenskapliga arbeten och hans omfattande korrespondens.

\section{Linnés mogna användning av latinet}

Vi skall nu gå in mer på hur Linné använde latinet. Innan vi gör detta, låt mig bara dra mig till minnes vilken syn på språkanvändning som Linné allmänt sett omfattade. Det kortaste svaret får vi av hans egen penna:

En simpel styl, korta ord med ren mening, och undvikande av Tautologie är dett som giör ens skrifter tydeligare. Mången tänker sig wara mycket klar då han widlöftigt beskrifver dett som kort älliest sägas kunne; hwilken doch är alltid obscur att förstå och ledsen att läsa. Men en ren och rätt method, som är själen af all wettenskap, är just den som giör all ting så makalöst lätt.

Ty har mitt förnämsta ändamål warit att skrifwa scientifices äller en ren method. (ur Vulcanus Docimasticus eller Handledning uti proberkonsten 1734.) ${ }^{3}$

Det korta och koncisa var hans stils adelsmärke, och det omdömet gäller alla hans genrer. I landskapsresorna vara hans svenska avväpnande; där finner vi att hans öppna öga och friska sinne kunde låta ett faktiskt konstaterande klinga som ett stycke lyrik, se nedan s.10.

\section{Linnés vetenskapliga språk}

Själva kärnan i Linnés språkliga program var att banta bort allt överflödigt. Det sköna i språket kom inte fram genom utsmyckning utan genom kondens genomskinlighet, "en ren och rätt method" som han själv skrev. Denna linje följde han konsekvent i sitt liv och sina verk.

2 Svartbäcken är en stadsdel i Uppsala, som dominerades av enkelt folk, t.ex. hantverkare. Ett latin som föreges vara obildat och okunnigt associerades då med denna stadsdel.

3 Citat från C. Linnaeus Vulcanus Docimasticus. Fahlun 1734. Efter originalmanuskriptet i Linnaean Society utgivet av G.A. Granström, Uppsala 1925. Tyvärr utan sidangivelse i Jönsson 2000, not 83. 
Hans avsikt att beskriva och systematisera ett enormt material ligger i linje med detta. Vilken var då den faktabotten Linné stod på när han började sitt vetenskapliga arbete? Den tradition man brukar framhäva för att beskriva hans användning av latinet för vetenskapligt bruk börjar med Aristoteles och fortsätter med Plinius d.ä. och Seneca. Aristoteles' (445-385) Zoologi (i latinsk översättning) hade satts i hans händer redan av hans fader. Från den lärde han den s.k. polynomiala beskrivningen av växter, en första typ av botanisk diagnos efter vissa principer. Aristoteles elev Theophrastos (370-287 f.Kr.), som också blev hans efterträdare som föreståndare för Lykaion, var botaniker och upphovsman till grundläggande beteckningar på växtens delar in på 1500-talet, liksom hans förteckning av ett 500-tal växter i den till lycéet hörande trädgården fortlever in i vår tid.

Plinius d.ä. (23-79 e.Kr) mötte Linné förmodligen redan på gymnasiet, förmedlad genom lektor Rothman. Plinius Naturalis Historia var en encyklopedisk sammanställning över den tidens vetande, av vilket en del är bevarat och något är tillgängligt genom senare svenska översättningar fotnoteras: Om bildkonsten övers Ellenberger Göteborg 1997, Om människan övers. Önnerfors. Jonsered 2000 och Om fåglarna övers. Nilsson Lund 2003. Seneca d.y. ( $4 \mathrm{f} \mathrm{Kr}-65$ e.Kr) var inte bara författare av moralfilosofiska epistlar och läsedramer med motiv från grekisk tragedi utan skrev också ett naturvetenskapligt verk, Naturales quaestiones, Naturvetenskapliga undersökningar, som till medeltidens slut haft en stor användning och påverkan.

Skolan och utbildningsväsendet, som övertagits från grekerna, hade på många håll en nedgångstid under 400-700-talen. Klostren befordrade dock både kristen och antik kunskap, skrev av handskrifter, undersökte texterna och undervisade om deras innehåll. De olika ordnarnas utbildningscentra fick på en del håll en mer självständig ställning. De blev helt enkelt de nya universiteten. Sorbonne i Paris är exempelvis sprunget ur klostret St Denis.

Genom universitetsrenässansen på 1100-1200 talen kom en ny våg av vetenskapligt tänkande att växa fram, den s.k. skolastiken. De mest kända representanterna för denna metod är dominikanermunkarna Albertus Magnus och Thomas av Aquino. De flesta menar idag att skolastikens systematiska sätt att med hjälp av dialoger och syllogismer undersöka tänkandets bärkraft och att offentligen diskutera teser i själva verket var en sådd till moderniteten och en grund för den västerländska moderna vetenskapligheten. Albertus (1193-1280) bidrog med 142 botaniska termer i sin De vegetabilibus Libri VII.

Allt i den västerländska vetenskapen, som från 1500-1600-talet alltmer får modern prägel, försiggår på latin; det gäller undervisning, seminarier, forskning, korrespondens, samtal, disputationer och publicering. I denna nylatinska miljö blir språket en mångsidig alstrare av begrepp, somliga helt nya, andra lånade från grekiskan. Begreppen börjar nu tätna och vetandet öka inom astronomi, medicin och botanik. De första kända namnen under den nya epoken är Valerius Cordus' (1515-1544) Historia plantarum och Leonhart Fuchs' (1501-56) De historia stirpium följda av Malpighi, Jung, Camerarius, Ray och Tournefort under det följande seklet. De senare påverkade Linné.

Det fanns alltså ett inte obetydligt material av traderade latinska termer för växter och deras beskrivning, som alltmer pockade på en undersökning och en organisation av det som var 
känt, både från källor och verklighet. En viktig faktor var den växande kunskap som fördes med upptäcktsresande och världsomseglare till Europa.

I de äldsta botaniska texterna, de flesta från grekiskt språkområde, finns således många namn, som dels är äktgrekiska, men också importer från andra språk och från ännu äldre östmediterrana språk, som ibland går under samlingsnamnet thrako-pelagiska. Romarna förde detta vetande vidare, tog upp andra språks benämningar och lånöversatte. Rätt få äktlatinska växtnamn finns traderade, utan det stora flertalet är nybildningar.

Termernas kulturhistoriska spegel är en rik skatt att ösa ur som vi här inte kan ägna någon uppmärksamhet. Allmänt kan sägas att de grekiska och romerska naturvetenskapliga författarna i regel använde ett enda namn, det folkliga för varje växt, men ibland särskilde de arter genom tillagda epitet som betecknade färg, växtplats, hemland, likhet, användning etc.

När artkännedomen under medeltiden ökade, var principen fortfarande densamma, men de artskiljande tilläggen växte till diagnostiska fraser.

Ett prov på Linnés framställningskonst i en växtdiagnos finns exemplifierat på bild 1 (se nästa sida). På den nedre delen beskrivs de språkliga elementen i hans berömda binära nomenklatur.

På bild 1 (bilaga 1) är en äldre diagnostyp återgiven (Tournefort: Institutiones Rei herbariae 1700), som i en enda mening försöker beskriva hela släktets karakteristika. Eftersom det är en enda mening språkligt sett är den syntaktiskt sammanbunden av verbformer. På den mittre delen återfinns Linnés motsvarighet. Linné har, till skillnad mot Tournefort, enbart kortfattade beskrivningar av de separata växtdelarna. Här förekommer ingen syntax, endast substantiv som huvudord och adjektiviska bestämningar. Det blir en kontrollerad vokabulär, bunden och entydig till form och innehåll, lätt genom- och överskådlig, vilket gör jämförelser lättare.

\section{Linnés binära system}

Caspar Bauhin, Rivinus, Tournefort, Lang, Klein med flera gjorde före Linné försök att skapa en någotsånär enhetlig nomenklatur i en binär ordning. Detta misslyckades dock, om man med binär nomenklatur menar en konsekvent användning av enordigt släktnamn följt av ett enordigt artepitet.

Linné hade tidigare använt diagnostiska fraser som artangivande (nomina specifica). I ett växtregister i slutet av sin Öländska och Gothländska resa (1745) och i växtförteckningen i Pan Suecicus (1749) använde han emellertid konsekvent epitheton quoddam loco differentiae (ett epitet i stället för diagnostisk fras). Det är detta artepitet som sedan i Philosophia botanica (1751) kallas nomen triviale och säges vara vocabulum unicum ('ett enda ord') och vocabulum libere undequaqua desumptam (ett ord taget fritt varifrån som helst). Enordiga artepitet infördes så i marginalen i Species Plantarum (1753) för växtriket och i 10:e upplagan av Systema Naturae (1758) även för djurriket, utan att för den skull slopa nomina specifica-fraserna. Som artepitet använde Linné ofta äldre enordiga växt- och djurnamn, vilka han skrev ned med stor begynnelsebokstav; i andra fall hämtade han artepiteten ur diagnostiska nomina specifica antingen genom att endast behålla det första ordet i dessa eller genom att 
The following is a typical description in Tournefort's Institutiones Rei herbariae (1700): 'Hyoscyamus est plantae genus, flore A monopetalo, infundibuliformi \& multifido: ex cujus calyce $\mathrm{C}$ surgit pistillum $\mathrm{D}$ infimae floris parti $\mathrm{B}$ adinstar clavi infixum, quod deinde abit in fructum $\mathrm{F}$ in ipso calyce reconditum $\mathrm{E}$, ollae similem, operculo $\mathrm{HK}$ instructum \& in duo loculamenta GG divisum septo intermedio I, cui adhaerescunt plurima semina L.'

The letters A, B, C, etc., refer to the illustration on Tournefort's Plate 41 (Fig. 7). To be noted are the verbs est, surgit, abit and adhaerescunt, the
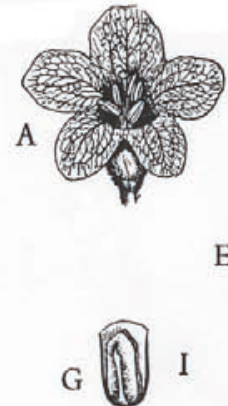

A

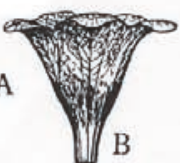

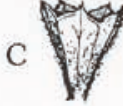

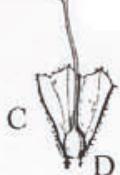

D H
$\mathrm{E}$

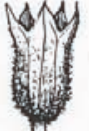

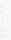

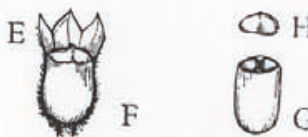

(6) $\mathrm{K}$
L $\because 0^{\circ}$

Fig. 7 Hyoscyamus niger; Henbane

A, corolla; B, corollae pars inferior; C, calyx; D, pistillum; E, calyx fructifer; E, F, fructus, dimidio calycis demoto; H, fructus operculum a latere visum; $G$, fructus pars inferior; $I$, fructus septum; $K$, fructus operculum ab infra visum; L, semina (drawing by Priscilla Fawcett, based on Tournefort, Institutiones Rei herbariae, t. 42;1700)

whole forming one sentence: 'Hyoscyamus is a genus of plants with a monopetalous funnel-shaped and multifid flower, from the calyx of which arises the pistil', etc.

In 1737 in his Genera Plantarum Linnaeus described the same genus as follows:

HYOSCYAMUS* Tournef. 42. Riv. I. 152, 153.

CAL: Perianthum monophyllum, cylindraceum, inferne ventricosum, ore quinquefido, acuto, persistens.

COR: Petalum infundibuliforme. Tubus cylindraceus, brevis. Limbus erectopatens, semiquinquefidus: laciniis obtusis, unica reliquis latiore.

STAm: Filamenta quinque, subulata, inclinata. Antherae subrotundae.

PIST: Germen subrotundum. Stylus filiformis, longitudine staminum. Stigma capitatum.

PER: Capsula ovata-obtusa, linea utrinque insculpta, bilocularis, duabus capsulis arcte approximatis, tecta, operculo horizontaliter dehiscente.

SEM: numerosa, inaequalia. Receptacula dimidiato-ovata, dissepimento affixa.

Språkligt ser således Linnés binära kod ut som töljer:

Släktnamnet (och ev undersläktnamn) är antingen

1. Ett substantiv i nominativ singularis Ex. Quercus, 'ek' eller

2. ett substantiverat adjektiv i nominativ singularis, ex. Polygala 'mjölkrik' De antika orden behåller sina ursprungliga böjningsformer.

Artepitet (art- underarts- varietets- form-) är

1. ett adjektiv (el. adjektiviskt använt substantiv) som till genus rättar sig efter släktnamnet. Ex. Lilium candidum 'vit lilja'

2. ett substantiv eller substantiverat adjektiv i nominativ singularis. Ofta är detta ett förlinneanskt släktnamn eller ett inhemskt namn, såsom en apposition till släktnamnet, t.ex. Parnassius apollo.

3. ett substantiv eller substantiverat adjektiv i genitiv, angivande upptäckare eller annan person som hedras, växt- eller uppehållsplats, blomningstid, värdväxt eller värddjur, sjukdom som förorsakas av växten o.s.v. Exempel: Primula veris, Vårens $\mathrm{P}$, Taraxacum Sulitelmae T. från Sulitelma

Bild 1: Ur Stearn, William T., Botanical Latin, 4th ed., repr. 2005. 
av två ord i dessa göra ett. Exempel: C Bauhins Ranunculus aconitifolius albo flore blev hos Linné Ranunculus aconitifolius och Tourneforts Cardamine alpina minor Resedae foliis fick formen Cardamine resedifolia.

\section{Linnés lån}

Linné griper inte sina namn ur luften utan hämtar ord från mytologi, ortnamn och botanikers namn. De närmare källorna till Linnés binära släkt- och artnamn, först redovisade i index till hans Öländska och Gotländska resa 1745, och mer fullständigt i Species plantarum 1753, har visat sig vara, förutom all den läsning han gjorde som gymnasist, Fabulae av Hyginus, vars verk om mytologi, har gått förlorat; Hyginus var föreståndare för det Palatinska biblioteket (64 f.Kr-17 e.Kr). Han hämtar även ord från Benjamin Hederichs mytologiska uppslagsverk Grundliches Lexikon mythologicum. Den tidsmässigt mest aktuella källan i samtiden var Caspar Bauhins Pinax (1623) en utbyggd generisk specifik taxonomi efter tysken Konrad Gesner (1516-65).

Resultatet av hans botaniserande blev en blandad kompott av frukter. Mytens personer återkom gång efter annan. Bland insekterna fanns t.ex. Papilio Priamus. Berömd är den vilda fjällblomman Andromeda, rosling, fäst vid ett gräs, men nerböjd som sin mytologiska förebild som fjättrades vid en klippa på order av den avundsjuke Jupiter Ammon, Egyptens övergud. Linnés vurm för mytologi avslöjas också i boktitlar som Pan Suecus eller Pandora Insecto-rum.

Linné skapade även helt nya ord med klassisk botten. Av de större botaniska begreppen är han far till pollen, frömjöl, petalum, kronblad och stigma, märket; de senare med grekisk bakgrund men utan anknytning till botanik. En viktig komponent är alla suffix och prefix som nybildas eller används på ett nytt sätt, t.ex. acutiusculus 'liten spetslik', subcaudatus 'nedtill svansformad', adjektivkomposita som curvato-multangulus 'böjd och flerflikig'.

Låt mig till denna blomsterbädd få foga ett för latinet okänt redskap från den svenska bondmorans rike, trampbrädet, som Linné förvandlade till valgium.

Sammanfattningsvis gör Linné så att han väljer, organiserar och standardiserar en vildvuxen flora av termer. Han skapar därvid ett antal nya begrepp, hämtade från brukbara grekiska eller latinska baser med tillägg av gängse prefix eller suffix. Allt inordnas och underordnas sedan i hans system, som först 1905 vinner officiellt internationellt burskap.

\section{Landskapsresornas latin}

Det kan tyckas kuriöst att i svenskspråkiga texter som landskapsresorna är infoga ett lärt språk. Det är ju förståeligt att nämna facktermer i en bok menad för lärt och kunnigt folk, men här beströs den löpande texten med citat och formuleringar som kräver latinkunskap och klassisk beläsenhet. 
I Iter Lapponicum kan det se ut på följande sätt:

5 Junii . . J Jag undrade, att lapparne eij bygga sig ı 6 à 20 små huus, uti hka de kunne gå erecti, emädan skogen ha de på sig. Sed respondent, om sommaren ärom wij på ett ställe, i wintren på ett annat, 20 mihl kanske här ifrån, där wij få mossa till renmossa $=$ hieme wåra renar. Quaerebam, cur non colligant aestate muscum rangiferorum, ut ea praebeant hyeme in epulis? Negant, qvia aestate versantur ubi pisces; hyeme longe abhinc ubi crescit...

I3. dies optimus clarus et serenus ... I4. Då jay hafft andra gästgifwareg. och mitt emällan den och den 3 :die färgats öfwer en elf, straxt wisar sig en ugla, hkn litet då och då flyger frå mig. Jag i medlertijd tager till min lilla byssa, och kl. I2 en qvart äffter, ty natten war eij dett minsta mörk, på frijhand wågar ett skått, råkade, fast hästen gick i full gång, ja så att ena sidan aldeles skiämdes, att hon eij kunne upstoppas. vide descript.

Utdrag ur Iter Lapponicum. Rad 5-8 i översättning av Erik Wiberg: Jag frågade mig, varför de inte samlar renmossa på sommaren, för att ge den till foder (nämligen åt renarna; övers. anm.) på vintern? De förnekade det, eftersom de vistas där det finns fisk på sommaren; på vintern är de långt ifrån där den växer.

Här möter vi en text tagen direkt från dagboken. Det som språkligt kännetecknar denna text är de latinska termerna, vilkas användning dikterade av en strävan att snabbt diagnosticera vad han såg med de facktermer som stod till buds, och visa läkarens försök att med objektiva termer beskriva människors och miljöers egenskaper. Man kan diskutera varför Linné gjorde som han gjorde. Men kanske det går att förklara genom att dels se till hans naturvetenskapliga lidelse att kortfattat definiera vad han såg,'dels stryka under prägeln av dagbok, det omedelbara intrycket, som också har sin betydelse. Rolf Hillman menar att det: "I Linnés blandspråk ibland ligger en viss glädje med ett uns av lärd făfänga över att få röra sig med latinet, något av det akademiska livets frimureri” (1970, s. 46). Bengt Löfstedt (1986/87, s. 122) har pekat på Linnés bruk av latinet och dess förbindelse med klassiskt och annat språkbruk. Han ser under landskapsresorna att det finns likheter i form och avsikt - just i växlingen mellan modersmål och tillägnade språk - mellan Luthers Tischreden och Linnés provinsskildringar.

\section{Linnés muntliga bruk av latin}

Ytterligare en aspekt av Linnés latinanvändning är hans - förmodligen dagliga - bruk av muntligt latin. Detta var upptränat ända sedan trivialskolan, där språket både hördes och lästes, liksom på gymnasiet. Det var också det vardags- och specialistspråk genom vilket Linné inledde sin internationella karriär och klarade sin vardag 1732-1735, då han befann sig i Holland, England och Frankrike, vilkas nationalspråk han inte alls behärskade. Onekligen skulle det vara intressant att få uppspelade eller rekonstruerade några olika situationer där Linné använder talat latin. Vi kan nog, med ledning av hans skrivna latin och kunskaper om hans livliga och engagerande sätt, föreställa oss det ytterst sällsamma i att avlyssna en 
person, som spänner över sitt småländska modersmål, skolans talövningar över bragdrika romare, oöverskådligt och heterogent specialistlatin från olika epoker, samtida gängse samtalsprosa från de vetenskapliga salongerna i Europa och ett flitigt, om än med svenska uppblandat, föreläsningsspråk från akademien i Uppsala.

\section{Linnés korrespondens}

Jag vill nu uppmärksamma er på Linnés korrespondens, som var mycket omfattande.

Idag är ca 5800 brev kända till 200 mottagare i Sverige och 400 i utlandet. Det stora flertalet är avfattade på latin. Samlingen kastar ljus inte bara på Linné och hans vetenskap utan också över den dåtida vetenskapliga kommunikationen över huvud taget. Hur var då Linnés latin som han använde till vardags, utan korrektur och försköning?

Helheten får vi en uppfattning om i ett kort brev (se nästa sida) som Linné skrev till den tyske läkaren och botanikern Christian Gottlieb Ludwig i Leipzig ${ }^{4}$. Med honom har Linné utväxlat åtskilliga brev, som ibland vittnar om både klarspråk och ömsesidig uppskattning.

Brevet inleds med en rad artighetsfraser, där Linné gratulerar Ludwig till alla hedersomnämnanden han fått och för en bok som Linné erhållit genom hans förmedling. Därpå går Linné in på alla de vetenskapliga verk som Ludwig författat med Linné som mål, och Linné uppmanar honom att publicera sin egen metod. Själv kallar han sig en nyinskriven soldat. Sedan går han in på enskilda kontroverspunkter. Tydligen har släktet Pythia som Linné tidigare publicerat i Genera Plantarum tagits bort i den något senare Corollarium genus. Sedan omtalar han att han i två av sina verk uppkallat arter efter Ludwig och avslutar med förhoppningen att detta, trots att det sker i strid med hans egna principer, gjorts av uppriktig kärlek till honom som vän. Denna Linnétext har nästan enbart klassisk ortografi, men några avvikelser skall nämnas, inte minst i syntaxen. Låt oss saxa ur texten ovan (rastrerat) i svensk översättning:

Du borde inte bli arg på dem för att de inte fortsatt längre; de har inte sparat någon möda och ingen ansträngning, Eftersom jag själv mycket väl känner min egen svaghet, har jag aldrig varit så obetänksam att jag trott att jag själv på något sätt kunnat efterlämna något fulländat.

Här kan man mena att Linné tre gånger bryter mot klassiska regler. Parco måste enligt dem styra dativ, och här styr det ackusativ. Problemet är bara att såväl i arkaiskt som nyare latin är enbart det senare möjligt. Peparcerint är ett slarvfel. Linné visste att det heter pepercerint. Dessa exempel på språkfel kan avslutas med infirmatis, en hopskrivning för infirmitatis. Progredior är deponens i klassiskt latin och borde således fått formen progressus sum.

Det finns avvikelser från den vedertagna latinska formläran i detta brev som jag inte går in på här, liksom konjugationsöverklivningar och felaktig bisatskonstruktion. Men de kan förklaras som alternativt bruk i nylatinet eller som resultat av obefintlig korrekturläsning. Linné hade aldrig tid till sådant. Ingenstans i de citerade breven går felen egentligen ut över förståelsen av det skrivna. Detta brev är ganska rättvisande för frekvensen av formläre- och syntaxavvikelser man kan finna i ett handskrivet Linnébrev. På få ställen i breven går felen egentligen ut över förståelsen av det skrivna. Det rör sig om fel som i en ogranskad doktorsavhandling på engelska skriven av en svensk skulle kunna sett ut som följer:

4 Linnés brev nr L 0211 22/10 1737. 


\section{$\underline{\mathbf{L} 0211}$}

Carl Linnaeus [+] to Christian Gottlieb Ludwig [+]

Leiden, Netherlands, 22 October 1737 n.s.

Viro Experientissimo Celeberrimoque, D[omi]no M[onsieur] Chr[istiano] Gottl[ieb] Ludwig, Philos[ophiae] \& Medicinae Doctori, In Acad[emia] Lipsiensi Botanico \& Docenti, Salutem pl[urimam] dicit Car[olus] Linnaeus.

Ante triduum Tuas doctissimas literas die 14 augusti exaratas simul cum missis dissertationibus ad me accessere.[1]

Gratulor ex animo longe diu ante hoc promeritos in arte honores. Utinam proxime possem idem ad Professoris gradum publicum in Academia Lipsiensi, ut sub Tuo praesidio Te Maecenate effloresceret ars nostra diu neglecta, gratulari![2]

Gratias quas possum ago summas pro curiosissimis, quas ad me misisti, dissertationibus, Gratias pro doctissimo Tuo Programmate.[3] Utinam scirem, qua in re mutuis inservirem officiis,[a] me paratum reperires, spondeo!

Fuerunt autem Tuae literae simillimae dissertationis mihi oppositae. Sed id omne ab animo amicissimo profectum esse certus confido. Neque recuso doceri meliora. Utinam Tu propriam ederes methodum, qui tanto tamque sublimi gaudes judicio! Ego primus essem, qui sapientius dicta subscriberem. Nec ullo modo dubito, quin sapientius longe evitares non modo omnes errores, sed et ita absolveres, ut ne quidem dubia causari possent argumenta. Hoc certus spero, quod, si Tibi Deus annos concedat, in praxi Botanica relinquas orbi fundamenta solida, quibus superstrui potest tamquam immotis principiis ars, quam tantis in deliciis habent mortales. Interim Tu ut doctior longe \& sublimiori judicio felix ita et Sapientior facilis ignoscas, dum vides homines, quibus e viliori luto finxit praecordia Titan. Nec ipsis succenseas, dum nullos peparcerint [sic] labores, nullum inceptum,[b] quod[c] ipsis ultra progredi datum non fuit. Numquam eo temeritatis progressi [sic] propriae meae infirm[it]atis maxime ipse gnarus, ut crederem ullo modo me quid perfectum relinquere potuisse. Tyro sum; ero, dum vixero, nec perfectum vidi. Utinam Tu ante me scripsisses, longe amplius tunc prospexissem! Malevolorum tela non curo. Quis haec evitavit umquam? Gratulor me in Te immerens obtinuisse Amicum fidum, sc[ilicet] integerrimum, qui ut meorum errorum maxime gnarus ita et mei eo major Defensor in rebus infirmis, dum prodesse studueram. Occurrunt longe multa, quae ex iisdem quae mihi objecisti principiis, mihi paradoxa; occurrunt in Tuis. At de iis dubitare ne quidem mihi concedit ratio ulla. Non enim Te nil sine ratione sufficienti dicere posse nec de Te dubitare admit[t]eret candor, sc[ilicet] si des, quae[d] concepi[e] in amicum, qui se mihi toties tam fidum obtulit, ulla vera. Quo[f] ego Te animo prosecutus sum, licet absentem nec umquam visum, dabit suo tempore vaga fama. Dicant, quae de Te publice commentatus sum.

Numquam reticui argumenta, quae methodum meam infringerent. Ipse ea ingenue professus sum. Meam methodum naturalem numquam obtrusi. Longe aliud sentio. Videbis huc ex fragmentis methodi meae naturalis. [4] Videris itaque quasi de instituto contra me sensisse magis quam ex animi sententia. 
The thesis presented by Skeat is worth serious consideration, as are the the other models, explaining the birth of the scriptural codex, referred to above

These thesis presented by Skeat is worth serios consideration, which are the other models, explaining the birth of the scripture codex, referred to above

\section{Linné som festtalare och poet}

Ingen som läst Linné är omedveten om hans starka böjelse för det komprimerade uttrycket och hans dragning till romerska skalder, som Ovidius och Vergilius. Jag vill som sista exempel i denna artikel analysera ett inslag i Fundamenta botanica, nedskriven 1730, publicerad sex år senare. Det är närmare bestämt den högstämda dikten "Naturae querela ad Iovem" (Naturens klagan mot Jupiter), fogad till skriftens företal, författad av den blott 23-årige Linné. Den får stå som representant för Linné som latinsk versmakare. Kanske att texten också ger en vink om hans gåvor som akademisk festtalare.

\author{
Naturae Querelae ad Jovem \\ Ex praefatione Fundamentae Botanicae
}

Alma diu jacuit totum Natura per orbem neglecta et sine honore fuit sine numine numen Ad solium Jovis ibat et has de corde querelas expromsit laceros, ut erat, diffusa capillos:

"Nemo meas agnoscit opes; nec scilicet herbis numen inesse putat, quamvis latet abdita in meis visceribus vis magna, ex coelo ducta potestas.

Cur hominum tam segne genus pravumque moraris hactenus?" At solio tum Jupiter infit ab alto. Arridens blandam alloquitur sermone ministram: "Pelle metus, mea nata, et disjice nubila frontis.

Namque, ni fallor, erit, neque enim procul abfore credo tempus, quo nova gens priscos renovabit honores"

Tum pater inspiciens arcana volumina fati. Eresius primo se ostendit margine chartae.

Proximus huic, longo sed proximus intervallo Pedacius se offert, atque una Plinius exstat.

Plurima tunc atro fuit obscurata colore pagina Botanicae longumque inviderat arti, donec jam tandem revolutis ordine lustris Mathiolus priscos instauraturus honores communi impensa fraetus regumque favore.
Den vackra naturen låg länge $\mathrm{i}$ träda utöver hela vår värld och utan ära, en kraft utan kraft Naturen löpte fram till Jupiters tron, och avlät, som hon stod, med håret på kant, följande sar gade klagan från hjärtat:

Ingen vill kännas vid min makt, ingen tror att det finns en gudakraft i örterna, fastän den ligger dold i mina inälvors djup, en stor kraft, en makt sprungen från himlen.

Varför har du tills nu hållit tillbaka ett så slött och förvänt släkte?

Men då började Jupiter sitt tal från tronen den höga. Med ett leende håller han följande tal till sin blide tjänare:

Fördriv din fruktan, min dotter och skingra molnen från din panna. Ty det kommer, om jag inte tar fel, en tid, och jag tror inte den är avlägsen, när ett nytt släkte kommer att förnya de forna dygderna.

Sedan ser fadern in i Ödets hemliga skrifter. Eresius visar sig först från kanten av bladet. Närmast efter denne, men på långt avstånd, anmäler sig Pedacius och tillsammans med honom står Plinius. 
Hunc sequitur serie felici atque ordine longo illinc Caesalpinus et hinc par nobile fratrum Bauhini atque hac parte Columna et Clusius illa pluraque perpetua quae virent numina fama. Excipit hinc sacros argentea pagina visus. Breynius, Hermannus, Rheed et Morisonus in una heu nimium brevis ipse aevi! Mors improba coeptis invidet et vitam medio in conamine rumpit.

Rajus hic implet opus summaque coronide figit aureaque explicuit Plukeneti litera nomen.

Unus in hoc sacro Tornefortius margine splendit.

Rivinus resplendenti sese exerit aere.

Apparent instructi acie, sed non tamen omnes felices operum; infelix Kramerus et ausis ipse suis impar.
Men sedan var den största delen av sidan dold av svart färg, den hade länge känt avund mot den botaniska konsten fram till dess att slutligen, sedan sekler förlöpt, Matthiolus kommer för att återinsätta den forna äran, förlitande sig på det allmännas kassa och kunglig favör.

Följer på denne en lång och lycklig serie anförd av Caesalpinus, följd av bröderna Bauhin, och på ena sidan av bladet Columna och på den andra Lecluse och flera gudabestänkta berömdheter som grönskar för evigt. Därefter börjar en silverne sida skymta framBreyne, Herman, Rheede och Morison kommer fram på en gång. Ack, Morisons liv blev för kort. Den skändliga döden missunnar honom hans insats mitt $\mathrm{i}$ hans företag.

Ray avslutar däremot sitt verk och fäster däröver sitt slutsignum, men lämnar en gyllene bokstav att förklara Plukenet.

Tournefort lyser ensam på denna heliga kant. Rivinus lyser fram i skinande brons. De framstår alla i välordnat led, men ändå är inte alla ryktbara efter sina verk; Kramer, den olycklige, var inte själv i höjd med sin dristighet

Prosaöversättning: Erik Wiberg

Som en mer avancerad kria av en ung man, knappt ens uppstigen på forskarkarriärens första trappsteg, blir denna text intressant, eftersom den kastar ljus på hans användning av klassikerna och latinet. På köpet får vi också hans redan ganska klara uppfattning om botanikens stjärnhimmel. I korthet får vi här en vältalighetsövning över flera teman - sorg, luctus (v. 1-2), klagan, querela (v. 3-9). De följande raderna ger consolatio, tröst. Jupiter tröstar naturen och förutser att hon kommer att bli ärad i en nära framtid. Merparten av dikten (v. 14-35) är en lovprisning (laus), där Jupiter ser in i Framtidens bok och räknar upp dess kommande botaniska hjältar.

Vi kan i texten se anspelningar på kända topoi i den antika litteraturen. Ann-Mari Jönsson ${ }^{5}$ pekar på det epikuriska anslaget i dikten som påminner om Lucretius De rerum natura $(\mathrm{Om}$ tingens natur). Klagan inför Jupiter har en parallell i Vergilius' Aeneid, bok 1 (v. 227 ff) där Venus klagar över sin son, Aeneas' kval under resan från Troja. Tydlig är också allusionen på Aeneidens berömda bok 6, där Aeneas får det romerska rikets framtid föreställd för sig genom sibyllan i Cumae. Ovidius' Metamorfoser kommer i tankarna genom metallerna, silver, guld och brons från Quattuor aetates.

Har vi höglitterära anspråk kanske denna text inte håller måttet, men ser vi den som ett utslag av den tidens skolbildning blir bilden genast ljusare, ett personligt brutet budskap

5 Jönsson, 2000 s. 62. 
på en konventionell och välövad grund. Språket, vars form och ordval får kallas klassiskt i egentlig mening - flyter, även om hexametern inte alltid är så elegant. Det blir också mycket personligt linneanskt till innehållet genom hans rangplacering av naturen och dess förnämsta uttolkare, botanikerna, tycka vad man vill om hans egna preferenser.

\section{Slutvärdering}

Tre samtidsvittnen skall få avrunda denna artikel med korta omdömen om hans latin. Så här skriver Abraham Bäck, kanske Linnés närmaste vän, livläkare i Stockholm:

Det var honom inte gifvet att lära språk, för den orsaken mindre nögd med utlänningen, som ej kunde tala latin. På latin uttryckte han sin mening tort, lätt, nogare och kårtare än någon annan, men för övrigt gjorde han sig icke stor möda allenast saken var med naturen överensstämmande. (Bäck 1779, s. 77.)

Jean-Jacques Rousseau's bedömning i Letter on the elements of Botany addressed to a Lady:

Complaint has been made that the words of this language are not all to be found in Cicero. This complaint would be reasonable had Cicero written a complete treatise of Botany. Those words however are all either Greek or Latin, expressive, short, sonorous and even form elegant constructions by their extreme precision. It is in the constant practise of the art, that we feel all the advantages of this new language, which is convenient and necessary for botanists, as that of algebra is for mathematicians. (Rousseau 1807, s, 12.)

En mycket van kontinental latinanvändare, medicinprofessorn François Boissier de la Croix de Sauvages i Montpellier ${ }^{6}$ skriver så här:

Opus...vere aureum et, mote parvum, at reipsa maximum. Miror tuam sapientissimam breviloquentiam, tuum ordinem nitidissimum. Alii autores pauca multis verbis, tu multa paucis verbis profers pro more solito. ${ }^{7}$ (Linnaean Society of London, Collection of Letters.)

Låt oss nu summera vad som framkommit och försöka värdera Linnés latinanvändning.

Först skall sägas att Linné var en mycket mångsidig och flitig utövare av latinet och de genrer han inte använde var få. Också hans muntliga bruk av språket var omfattande. Det finns en gemensam nämnare för hans bruk av latinet, och det är kortheten i uttryckssättet. Linné är beroende av bestämda källor och mönster, från gymnasiets bildning, vedertagen terminologi och diagnostik från antiken och framåt samt samtida nylatinskt språkbruk. Han gjorde som latinist bestämda, originella och bestående bidrag till nyords- och begreppsbildningen. I denna mening var han en nydanare också internationellt sett. Linné var inte en polerad Cicero utan en otålig systematiker som inte så sällan drabbades av småfel i sina brev och otryckta verk. Dessa förringar dock på inget sätt hans ställning som kompetent latinanvändare på sitt område.

\footnotetext{
6 Brev 15/9 1751.
}

7 I översättning: Ditt arbete...är verkligen gyllene, det är litet i storlek, men i verkligheten mycket stort. Jag är förundrad över din synnerligen visa korthet i uttrycket och din glänsande ordning. Somliga författare säger få saker med många ord, men du säger många saker med få ord efter din vana. 


\section{Litteratur}

Bäck, A. (1779): Åminnelse-tal öfver (...)Välborne herr Carl von Linné (...) Den 5 December, 1778: Stockholm.

Carl von Linnés självbiografier (1957): På uppdrag av Uppsala universitet utgivna av E. Malmeström och A.Hj.Uggla. Uppsala.

Hillman, Rolf (1970): Svensk prosastil under 1700-talet: Dalin, Linné, gustaviansk talekonst. Stockholm.

Jönsson, Ann-Marie (2000): "Linnaeus's Svartbäckslatin as an International Language of Science". I Svenska Linnésällskapets årsskrift 2000/2001, s. 49-76.

Löfstedt, Bengt (1986): "Zu Linnés Latein". I Svenska Linnésällskapets årsskrift 1986/87 s. $118-134$.

Linnaean Society of London, Collection of Letters.

Rousseau, J.J. (1807): Letters on the Elements of Botany Addressed to a Lady. Translated into English with notes, and twenty-four additional letters fully explaining the system of Linnaeus by Thomas Martyn, London, $7^{\text {th }}$ ed.

Stearn, William T., Botanical Latin, 4th ed., repr. 2005, Portland, Oregon

\section{För vidare läsning}

Blunt, Wilfrid (2002): Carl von Linné. Stockholm.

Fries, Sigurd (utg.) (1971), Linnés språk och stil. Stockholm.

Fries, Sigurd (1996): "Lärdomsspråket under frihetstiden". I Svenska i tusen år. Glimtar ur svenska språkets utveckling. (red.) Lena Moberg och Margareta Westman. Stockholm.

Teleman, Ulf (2002): Ära, rikedom och reda. Svensk språkvård och språkpolitik under äldre nyare tid. Stockholm.

Widmark, Gun (1996): "Den lätta prosan växer fram". I Svenska i tusen år. Glimtar ur svenska språkets utveckling. (red.)Lena Moberg och Margareta Westman. Stockholm. 1996. 